\title{
Harnessing the Four Horsemen of Climate Change: A Framework for Deep Resilience, Decarbonization, and Planetary Health in Ontario, Canada
}

\author{
Vidya Anderson 1,*(i) and William A. Gough ${ }^{1,2}$ \\ 1 Climate Lab, University of Toronto Scarborough, Toronto, ON M1C 1A4, Canada; william.gough@utoronto.ca \\ 2 Department of Physical and Environmental Sciences, University of Toronto Scarborough, \\ Toronto, ON M1C 1A4, Canada \\ * Correspondence: vidya.anderson@utoronto.ca
}

Citation: Anderson, V.; Gough, W.A. Harnessing the Four Horsemen of Climate Change: A Framework for Deep Resilience, Decarbonization, and Planetary Health in Ontario, Canada. Sustainability 2021, 13, 379. https://doi.org/10.3390/su13010379

Received: 12 December 2020 Accepted: 29 December 2020 Published: 4 January 2021

Publisher's Note: MDPI stays neutral with regard to jurisdictional clai$\mathrm{ms}$ in published maps and institutional affiliations.

Copyright: $\odot 2021$ by the authors. Licensee MDPI, Basel, Switzerland. This article is an open access article distributed under the terms and conditions of the Creative Commons Attribution (CC BY) license (https:// creativecommons.org/licenses/by/ $4.0 /)$.

\begin{abstract}
Widespread implementation of nature-based solutions like green infrastructure, provides a multi-functional strategy to increase climate resilience, enhance ecological connectivity, create healthier communities, and support sustainable urban development. This paper presents a decision-support framework to facilitate adoption of green infrastructure within communities using the Climate Change Local Adaptation Action Model (CCLAAM) developed for this purpose. It also presents an ecosystems-based approach to bridging the gap between climate change mitigation and adaptation actions in Ontario, Canada. Green infrastructure could be a viable strategy to address multiple climate change impacts and support the implementation of the UN Sustainable Development Goals (SDGs).
\end{abstract}

Keywords: green roofs; green walls; tree-based intercropping; urban agriculture; urban forestry; nature-based solutions; green infrastructure; public health; food security; climate security

\section{Introduction}

Widespread implementation of green infrastructure can provide a nature-based solution to bridge the gap between climate change mitigation and adaptation actions. It also presents a unique opportunity to perform the dual functions of mitigation and adaptation simultaneously. Climate change mitigation is defined as an anthropogenic intervention to reduce the anthropogenic forcing of the climate system and it includes strategies to reduce greenhouse gas sources and emissions and to enhance greenhouse gas sinks [1]. Climate change adaptation is described as an adjustment in natural or human systems in response to actual or expected climatic stimuli or their effects, which moderates harm or exploits beneficial opportunities [1]. Nature-based solutions like green infrastructure can function as a complex form of adaptation that both minimizes the most harmful effects of climate change on human health and the environment while mitigating the greenhouse gas (GHG) emissions that cause climate change. Although there is common agreement that green infrastructure is a good thing and that it provides a mechanism for addressing climate change, what is missing is a clear understanding of how it can be leveraged as a complex nature-based intervention if it is strategically applied. This paper addresses this issue.

The International Union for Conservation of Nature (IUCN) defines nature-based solutions as "actions to protect, sustainably manage, and restore natural or modified ecosystems, that address societal challenges effectively and adaptively, simultaneously providing human well-being and biodiversity benefits" [2]. Nature-based solutions provide an umbrella descriptor for the five categories of ecosystem-based approaches of which green infrastructure is one [2-5]. Green infrastructure is a cross-sectoral approach to address the impacts of climate change. In addition, the implementation of green infrastructure has multiple environmental and health co-benefits for communities, that can reduce the impacts of 
climate change and the associated burden of illness. The application of green infrastructure can also increase health and environmental equity, and support implementation of the United Nations Sustainable Development Goals (UN SDGs) across communities in the face of a changing climate. The UN SDGs are a universal call to action to end poverty, protect the planet, and improve the lives and prospects of everyone, everywhere. There are 17 Goals as shown in Table 1 that have been adopted by all United Nations member states, including Canada, in 2015, as part of the 2030 Agenda for Sustainable Development to achieve the UN SDGs [6]. The 17 SDGs have 169 associated targets and over 230 indicators [7]. There are linkages and interdependencies between the SDGs. Addressing climate change can have positive benefits for biodiversity while sustainable agricultural practices can achieve food security, in addition to reducing both poverty and greenhouse gas emissions. Achieving the SDGs requires strategic implementation to ensure integration of the economic, social, and environmental dimensions of sustainable development. Malfunction in one dimension can influence the others [7]. Nature-based solutions like green infrastructure can address these societal challenges.

Table 1. The 17 UN Sustainable Development Goals.

\begin{tabular}{|c|c|}
\hline \multicolumn{2}{|c|}{ UN Sustainable Development Goals } \\
\hline Goal 1. No Poverty & End poverty in all its forms everywhere \\
\hline Goal 2. Zero Hunger & $\begin{array}{l}\text { End hunger, achieve food security and improved nutrition and promote } \\
\text { sustainable agriculture }\end{array}$ \\
\hline Goal 3. Health and Well-being & Ensure healthy lives and promote well-being for all at all ages \\
\hline Goal 4. Quality Education & $\begin{array}{l}\text { Ensure inclusive and equitable quality education and promote lifelong } \\
\text { learning opportunities for all }\end{array}$ \\
\hline Goal 5. Gender Equality & Achieve gender equality and empower all women and girls \\
\hline Goal 6. Clean Water and Sanitation & $\begin{array}{l}\text { Ensure availability and sustainable management of water and sanitation } \\
\text { for all }\end{array}$ \\
\hline Goal 7. Affordable and Clean Energy & Ensure access to affordable, reliable, sustainable, and modern energy for all \\
\hline Goal 8. Decent Work and Economic Growth & $\begin{array}{l}\text { Promote sustained, inclusive, and sustainable economic growth, full and } \\
\text { productive employment, and decent work for all }\end{array}$ \\
\hline Goal 9. Industry, Innovation, and Infrastructure & $\begin{array}{l}\text { Build resilient infrastructure, promote inclusive and sustainable } \\
\text { industrialization and foster innovation }\end{array}$ \\
\hline Goal 10. Reduced Inequalities & Reduce inequality within and among countries \\
\hline Goal 11. Sustainable Cities and Communities & $\begin{array}{l}\text { Make cities and human settlements inclusive, safe, resilient, and } \\
\text { sustainable }\end{array}$ \\
\hline Goal 12. Responsible Production and Consumption & Ensure sustainable consumption and production patterns \\
\hline Goal 13. Climate Action & Take urgent action to combat climate change and its impacts \\
\hline Goal 14. Life Below Water & $\begin{array}{l}\text { Conserve and sustainably use the oceans, seas, and marine resources for } \\
\text { sustainable development }\end{array}$ \\
\hline Goal 15. Life on Land & $\begin{array}{l}\text { Protect, restore, and promote sustainable use of terrestrial ecosystems, } \\
\text { sustainably manage forests, combat desertification, and halt and reverse } \\
\text { land degradation and halt biodiversity loss }\end{array}$ \\
\hline Goal 16. Peace, Justice, and Strong Institutions & $\begin{array}{l}\text { Promote peaceful and inclusive societies for sustainable development, } \\
\text { provide access to justice for all and build effective, accountable, and } \\
\text { inclusive institutions at all levels }\end{array}$ \\
\hline Goal 17. Partnerships for the Goals & $\begin{array}{l}\text { Strengthen the means of implementation and revitalize the global } \\
\text { partnership for sustainable development }\end{array}$ \\
\hline
\end{tabular}

Successful implementation of the SDGs must occur across the global, regional, and national levels and this implementation is reliant on the sustainable development policies of individual countries. While the UN SDGs provide a compass to align national poli- 
cies with international commitments, local governments and communities are integral to transforming these goals from vision to reality [6].

\section{Green Infrastructure Benefits}

Green infrastructure provides a series of complex adaptation interventions to address climate change impacts. In addition, green infrastructure delivers an effective instrument for climate change mitigation by reducing GHG emissions from the built environment and providing carbon sequestration capacity. Emissions reductions and enhancement of carbon sequestration capacity are essential to mitigating climate change. Although the application of green infrastructure provides a mechanism for addressing climate change, each application is a complex nature-based intervention with unique characteristics and multiple co-benefits that can be strategically leveraged. Green infrastructure interventions share common functions as illustrated in Figure 1, while others are exclusive to particular applications. These functions include: air pollution abatement; temperature regulation; carbon sequestration; increased biodiversity and pollinator support; building energy efficiency; and stormwater management.

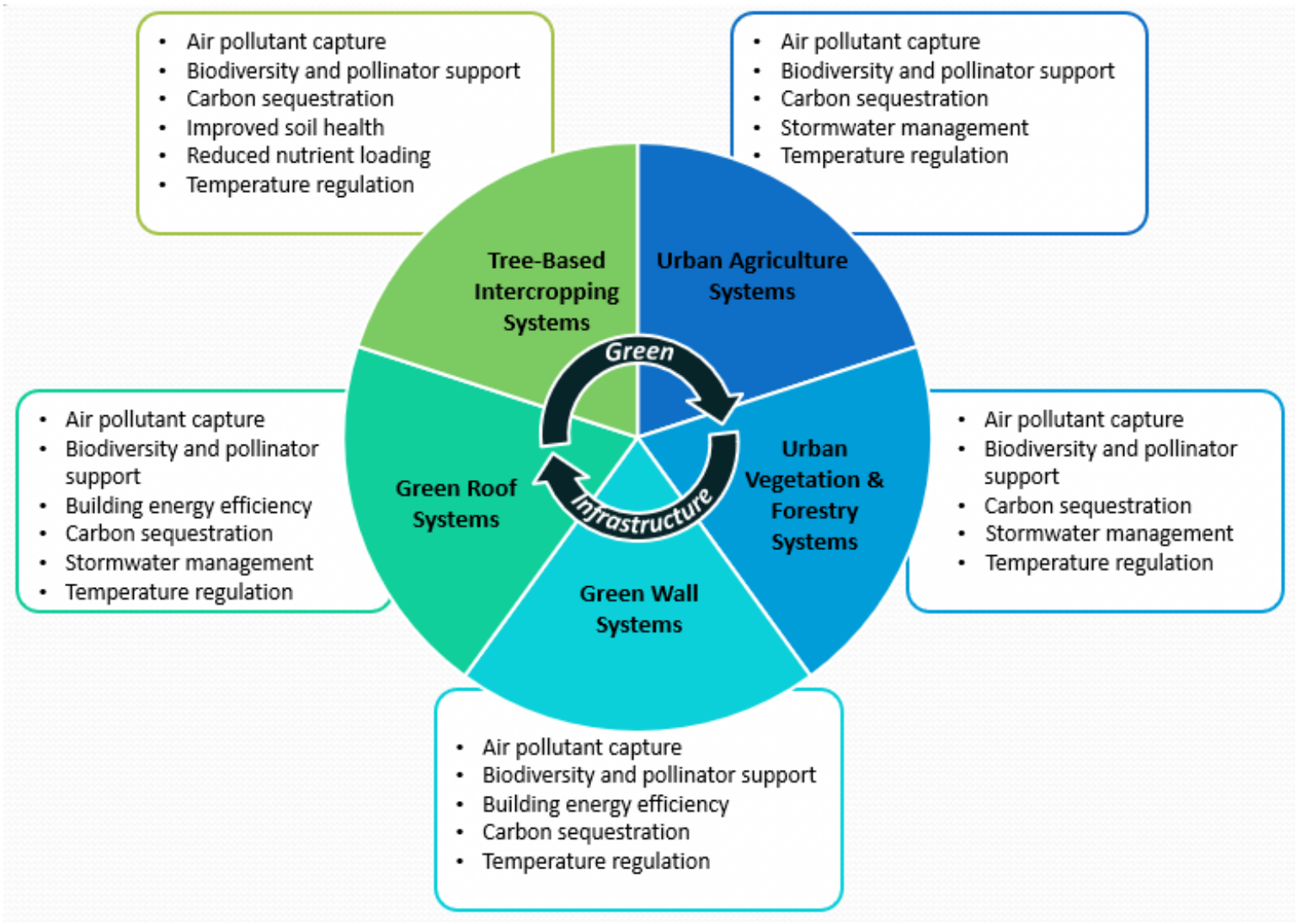

Figure 1. Green infrastructure form and function (Source: $[3,8,9]$ ).

Green infrastructure is broadly defined as inter-connected networks of natural and engineered green space that provide diverse ecosystem services [3,8,9]. As shown in Figure 1 , applications of green infrastructure can be categorized into five areas: green roofs, green walls, urban vegetation and forestry, urban agriculture systems, and tree-based intercropping systems $[3,8,9]$. Green roofs can be extensive, weighing less because of shallower depth and allowing for sloped roof application. Green roofs can also be intensive wherein there is substantial depth to the soil layer and greater variety in vegetation [3,8-10]. Green walls are building façades covered by plant growth or vegetated structures attached to building facades that are fed by automatic fertilization and hydration systems $[3,8,9,11,12]$. Urban vegetation and forestry include shrubs, bioswales (e.g., vegetated ditches for stormwater 
storage, drainage and infiltration), green permeable pavements (e.g., paved surfaces replaced with grass or herbs), rain gardens and trees [3,8,9,12,13] (Nowak et al., 2018). Urban agriculture systems include growing roofs, rooftop gardens, market gardens, community gardens, and micro gardens $[3,8,9,14,15]$. Tree-based intercropping systems are agricultural lands where trees or shrubs are inter-cropped with plants such as winter wheat, hay, corn, etc. $[3,8,9,16]$.

Although the benefits of green infrastructure have been established in the scientific literature as noted above, studies have focused primarily on single applications of green infrastructure and individual benefits. In addition, the policy instruments that enable the implementation of green infrastructure are often varied and not coordinated in any strategic way to facilitate wide adoption. Varied and variable green infrastructure nomenclature also presents a challenge. Without a common lexicon and shared understanding, the pace of uptake and mainstream implementation of green infrastructure will be slow. The differences in nomenclature present a unique challenge for decision-makers in whether to adopt green infrastructure as a climate change intervention and allocate resources for implementation. Implementation of green infrastructure in Ontario, Canada has not occurred in a coordinated way that maximizes environmental and human health co-benefits, and the ability of communities to implement green infrastructure locally varies in terms of knowledge, capacity, and resources. To facilitate the widespread implementation of green infrastructure, communities and decision-makers need guidance and support in evaluating which applications of green infrastructure are most appropriate in addressing the social and environmental impacts of climate change locally. In addition, localizing the SDGs requires guidance at the community level. Effective action can only occur if climate change is recognized and managed as an inter-disciplinary and cross-sectoral problem; and green infrastructure is strategically applied as a complex nature-based intervention.

This paper presents an original decision-support framework for deep resilience through the implementation of green infrastructure within communities using the Climate Change Local Adaptation Action Model (CCLAAM) developed for this purpose. The term 'deep resilience' defines an intervention that can perform the dual function of both adaptation and mitigation simultaneously, restore both anthropogenic and natural systems, and improve planetary health. Both adaptation and mitigation measures are necessary, and as such must work in concert to reduce the environmental and societal disruptions of climate change [17]. The development of this framework uses Ontario, Canada as case study. Put simply, this is a decision-support framework that accounts for the capacity of communities to adapt to climate change and implement the UN SDGs locally. The CCLAAM uses Theory of Change methodology to address the four categories of climate change impacts illustrated in Figure 2. The impacts of climate change are manifested in various ways. Some, such as extreme weather events, are obvious as their intensity, duration and frequency grows. Other impacts may seem less obvious as their effects are cumulative. In order to frame the catastrophic impacts of climate change and a decision-support framework in a comprehensive way, the biblical and apocalyptic metaphor of the Four Horsemen who represent War, Famine, Pestilence, and Death, are used to categorize the impacts of climate change. The decision support framework presented in this paper provides a pathway to address these impacts. 


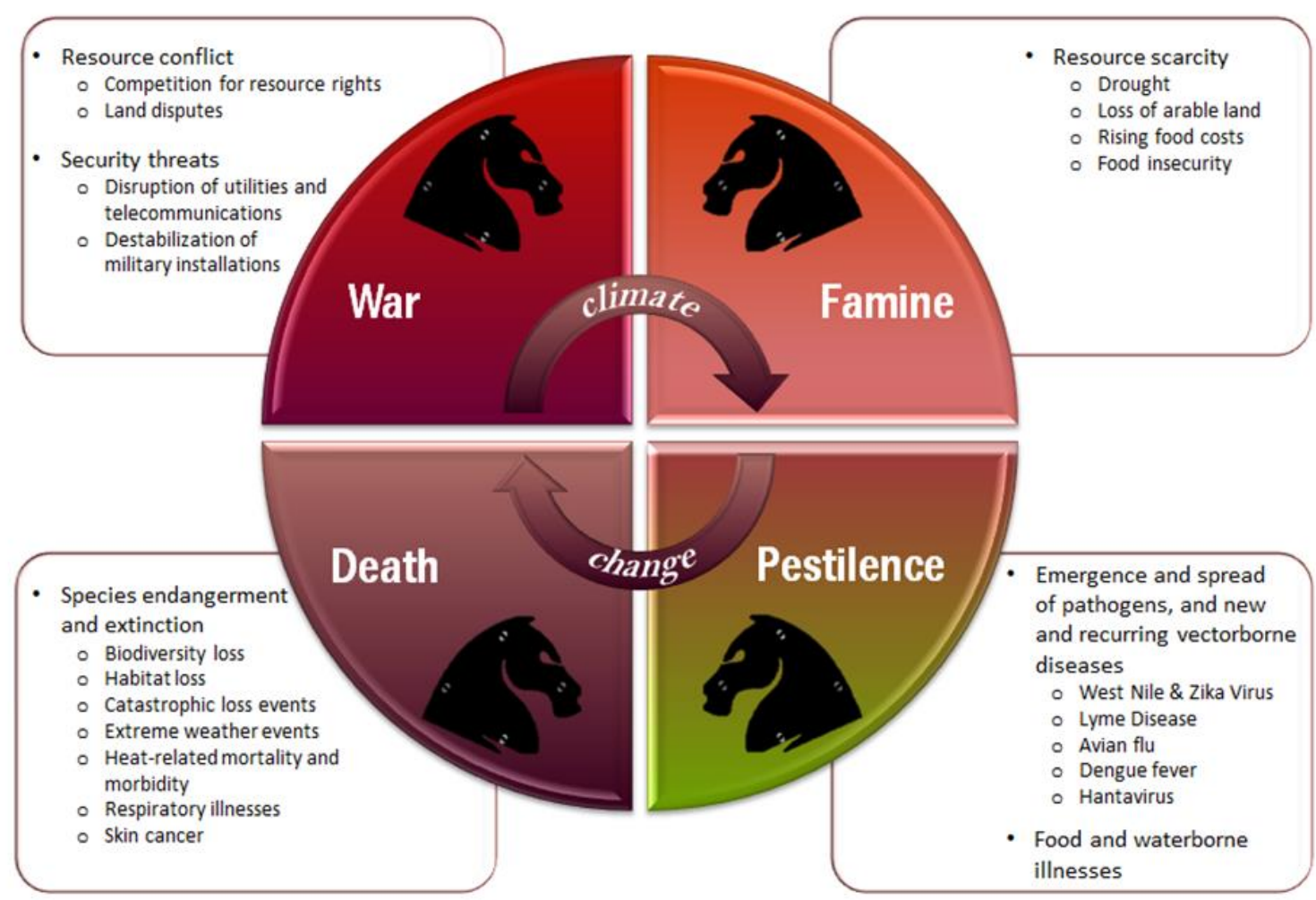

Figure 2. The Four Horsemen of climate change — categories of climate change impacts, war, death, famine, and pestilence (Source: [8]).

\section{Methodology}

To support the development of the decision-support framework and CCLAAM tool, a theory of change was established which postulates that when communities come together and implement multiple activities to support the widespread application of green infrastructure, everyone will be better prepared to manage the impacts of climate change across Ontario, Canada and protect the health and well-being of the people living and working in the province. Theories of change support monitoring and evaluation in order to facilitate greater understanding and assessment of impacts in areas such as governance, capacity building and institutional development that can be challenging to measure. A theory of change provides a causal framework of how and why interventions or actions occur within specific circumstances to achieve desired outcomes [18]. It provides a roadmap of how to achieve a desired end by identifying rationales for preconditions and [18].

Theory of Change methodology is rooted in the evaluation field. The term "theory of change" describes a set of assumptions that explain the various stages leading to a longterm goal and the interdependencies between program activities and outcomes that occur throughout the process [19-21]. By specifying the theories of change that influence complex initiatives, this process can improve evaluation and the ability to attribute outcomes to the goals set out in the theory of change. Planning and evaluation processes that utilize theories of change have become widespread among philanthropic organizations, government agencies, international non-governmental organizations, and the United Nations [19].

To support the theory of change that governs the decision-support framework and the CCLAAM, four strategies were established with a series of activities and corresponding outcomes to address the four categories of climate change impacts illustrated in Figure 2. The four strategies support the supposition that when communities come together and implement multiple activities to support the widespread application of green infrastructure, everyone will be better prepared to manage the impacts of climate change across Ontario, Canada and to protect the health and well-being of the people living and working in the province. The strategies include: (1) increasing the adaptive capacity of communities to 
reduce resource conflict and security threats to address the Horseman of War category of climate change impacts; (2) increasing the adaptive capacity of communities to manage the impacts of resource scarcity to address the Horseman of Famine category of climate change impacts; (3) increasing the adaptive capacity of communities to reduce and prevent the spread of pathogens and vector-borne diseases; and food and waterborne illnesses to address the Horseman of Pestilence category of climate change impacts; and (4) increasing the adaptive capacity of communities to reduce and prevent species endangerment, extirpation, and extinction to address the Horseman of Death of climate change impacts.

Each of the four aforementioned strategies has a corresponding set of activities and associated outcomes. The activities and outcomes that provide the basis of the decisionsupport framework and CCLAAM were developed using the results from five different studies. The first study undertaken was a systematic review deconstructing green infrastructure form, function, and nomenclature to provide an understanding of how green infrastructure works as a complex intervention, its characteristics, the metrics for performance and regulatory enforcement, and the multiple co-benefits that can be leveraged [8,9]. The second study undertaken was a health equity impact assessment of green infrastructure implementation in Ontario that evaluated the public health impacts and community benefits of publicly accessible and productive (i.e., allows for the production of food) green infrastructure such as green roofs, green walls, rooftop gardens, community gardens, etc. [8]. The health equity impact assessment process is widely used and supported by the World Health Organization [22] to identify how a policy or strategy may impact the health of population groups in different ways [23]. The third study undertaken was a regulatory impact analysis of the policy instruments which govern the implementation of green infrastructure in Ontario, Canada [8]. Regulatory impact analysis (RIA) is a systematic approach to critically assessing the positive and negative effects of proposed and existing regulations and non-regulatory alternatives [24,25]. The fourth study undertaken was a controlled field study to evaluate to the capacity of green infrastructure applications to regulate urban surface temperature in Toronto, Ontario, Canada [8]. The fifth study undertaken was a controlled field study to evaluate the capacity of multiple green infrastructure application to reduce ozone, nitrogen dioxide and carbon dioxide concentrations across different morphologies in Ontario, Canada [3,8].

\section{Results}

The Climate Change Local Adaptation Action Model (CCLAAM) is divided into four sections that define outcomes over the short, intermediate, and long term to address the four categories of climate change impacts through the implementation of different applications of green infrastructure.

\subsection{Climate Change Impact Category: War}

Climate change is a threat multiplier. It exacerbates vulnerability across sectors and can affect critical socioeconomic factors. For example, damage and loss of access to transportation systems due to extreme weather events, have an impact on food access and distribution, the movement of goods and services, and employment [26,27]. Climate change can also intensify security risks through its impact on the infrastructure and resources such as energy production and distribution, transportation networks, water supply and management, and agricultural and food production systems, which are the foundation of a stable and functioning society $[26,28,29]$.

Climate change poses both a direct and indirect threat to human, national, and international security. This threat stems from the manner in which climate change influences pre-existing security conditions $[26,28,29]$. Direct threats include impacts on military installations from extreme weather events and changes in sea levels, in addition to extreme weather impacts on critical infrastructure (e.g., energy, communications, financial and transportation) that can deteriorate the social and economic sustainability of a nation state. In some cases, the physical threat of climate change is so extreme (e.g., coastal communities, 
communities in the far North, low-lying islands) that the very existence of a community or a nation state may be called into question [26,28-30].

Climate change can also increase pressure on resources and infrastructure thereby presenting an indirect security threat. Growing pressure on resources and infrastructure can reduce the governing capacity of nation states and can exacerbate civil unrest, population displacement and disruption of livelihoods $[26,29,31,32]$. The dynamics of international security in geostrategic environments like the Arctic can also be affected by climate change $[26,29,31,32]$. Climate change is a stressor and a threat multiplier that can upset the proverbial applecart affecting security on multiple fronts.

The strategy and associated outcomes described in Table 2 support reduction of resource conflict and security threats by reducing pressures on natural resources that are a catalyst for conflicts, and by increasing the resilience of critical infrastructure which if damaged has a destabilizing effect on communities. Flooding from extreme weather events can significantly impact infrastructure and impervious surfaces throughout the built environment exacerbate its effects. The application of green infrastructure in its various forms can manage stormwater, reduce flood risk, and reduce runoff and pollution. Green infrastructure can manage stormwater by providing water storage during rainfall events, reducing overland flows, and preventing sediment erosion and nutrient loading [12,33,34]. Stormwater management varies with each green infrastructure application and is influenced by factors including location, proximity to impervious surfaces, depth of soil or substrate, and type and ratio of vegetation. For example, the application of a green roof can reduce stormwater runoff and flooding from 50 to 100 percent depending on the depth of the substrate, roof slope and plant species [35]. Green roofs retain stormwater in the substrate which evapotranspires back into the atmosphere [35]. Water that is discharged from the green roof is delayed by the time required to fully saturate the substrate and eventually drain. This process can reduce the burden on municipal stormwater systems by preventing sewer overflow and potential downstream erosion [35]. Urban vegetation and forestry provide permeable surfaces for bioinfiltration which enables both evapotranspiration and groundwater recharge [33]. In addition, urban vegetation and forestry can reduce overland flows and discharges to receiving waterbodies [33]. Tree-based intercropping systems provide a buffer to reduce runoff and nutrient loading from agricultural fields to nearby water bodies [36], while urban agriculture systems decrease impervious surface area, retain stormwater and increase infiltration [14].

Table 2. Strategy and associated outcomes from activities that increase the adaptive capacity of communities to reduce resource conflict and security threats through the application of green infrastructure.

\begin{tabular}{|c|c|}
\hline Strategy & Outcomes \\
\hline \multirow{9}{*}{$\begin{array}{l}\text { 1. Increase the adaptive capacity of communities to reduce } \\
\text { resource conflict and security threats }\end{array}$} & - Reduce water quantity stress \\
\hline & $\begin{array}{l}\text { - Enhance the capacity of natural heritage areas to respond to } \\
\text { the effects of extreme weather events }\end{array}$ \\
\hline & $\begin{array}{l}\text { - Increase the ecological health and propagation of long-lived } \\
\text { tree and vegetative species }\end{array}$ \\
\hline & $\begin{array}{l}\text { - Reduce fragmentation of natural areas, degraded water } \\
\text { quality, and negative impacts to fish and wildlife habitat }\end{array}$ \\
\hline & - Maintain natural biodiversity \\
\hline & - Protect fish species, habitat. and the aquatic food web \\
\hline & $\begin{array}{l}\text { - Reduce and prevent service interruptions, damage, and } \\
\text { property loss }\end{array}$ \\
\hline & $\begin{array}{l}\text { - Reduce impacts on the local economy from utility and } \\
\text { infrastructure disruptions }\end{array}$ \\
\hline & - Increase resilience of critical infrastructure \\
\hline
\end{tabular}




\subsection{Climate Change Impact Category: Famine}

Weather variation affects crops and livestock thereby impacting food security. Food security is impacted by escalating food prices and food availability. Climate change affects the four dimensions of food security that include availability (i.e., the production and trade of food), supply stability, food access, and food utilization [37]. Food security is affected by the changing climate but the associated socioeconomic impacts such as changes to the flow of trade, food stocks and aid policy, are the most critical factors in food security $[26,38]$. The impact of climate change on food availability varies by region and geography. Where there is a reduction in the production potential of a jurisdiction that already has diminished land and water resources, climate change will exacerbate the burden of pre-existing food insecurity [39-41].

Weather variability, including the intensity, duration, and frequency of extreme weather events such as droughts and flooding, impacts food supply and food access. In addition, loss of arable land and viable fisheries from flooding and coastal erosion further exacerbates food insecurity [42]. Water scarcity and rising temperatures also have implications for food processing, consumption and the incidence of foodborne illness. In areas at greater risk of flooding, exposure to vector-borne and waterborne illnesses can increase, lowering capacity to produce and utilize food effectively [38].

The strategy and associated outcomes described in Table 3 can help to manage the impacts of resource scarcity and food insecurity by increasing food availability and food access and providing greater stability in the supply of food and water through implementation of green infrastructure. Through the widespread implementation of different applications of green infrastructure across communities, it is possible to increase food security by building redundancy and resiliency into the system by increasing food availability and access at the local level and reducing reliance on supply chains that can be negatively impacted by externalities such climate change [8,9]. Urban agriculture systems can reduce the food miles and carbon footprint associated with conventional agriculture through local food production and distribution $[8,9]$. These systems can also reduce the pressures on conventional agriculture and can improve food security when large-scale agricultural production is affected by weather variation $[8,9]$. Urban agriculture systems provide key ecosystem services including stormwater management and pollination $[14,43]$. Urban agriculture systems have also been shown to enhance insect and vertebrate diversity and to provide pollinator friendly habitat $[14,44]$. The application of tree-based intercropping systems improves soil health and increases bird and insect diversity and earthworm distribution [45,46]. Tree-based intercropping systems reduce the ecological impacts of agricultural production and create more bio-diverse and sustainable land-use systems $[16,45,46]$. Tree-based intercropping can reduce GHG emissions associated with conventional agricultural practices by reducing reliance on pesticides and fertilizers and increasing canopy cover $[16,46]$. These systems also act as a carbon sink by sequestering carbon in the trees and by enhancing soil carbon sequestration capacity through improved soil health [46]. Multiple green infrastructure applications can create a network of sites and spaces to provide wildlife habitat and increase habitat connectivity and biodiversity $[14,33,34,44]$. 
Table 3. Strategy and associated outcomes from activities that increase the adaptive capacity of communities to manage the impacts of resource scarcity through the application of green infrastructure.

\begin{tabular}{|c|c|}
\hline Strategy & Outcomes \\
\hline \multirow{7}{*}{$\begin{array}{l}\text { 2. Increase the adaptive capacity of communities to manage the } \\
\text { impacts of resource scarcity }\end{array}$} & $\begin{array}{l}\text { - Increase efficiency and conservation in water use to maintain } \\
\text { future demands for water within sustainable limits }\end{array}$ \\
\hline & - Improve water quality \\
\hline & - Maintain healthy aquatic ecosystems \\
\hline & - Enhance and protect groundwater recharge areas \\
\hline & - Increase food security \\
\hline & - Facilitate more equitable food access \\
\hline & - Reduce food miles \\
\hline
\end{tabular}

\subsection{Climate Change Impact Category: Pestilence}

With warmer summer temperatures and shorter winters, the risk of diseases (e.g., Lyme disease, West Nile, and Zika virus) transmitted by mosquitoes, ticks and other vectors is increasing due to ecological changes, increased human exposure, and faster maturation cycles for pathogens [27]. Exposure to pathogens which are sensitive to climate can occur through direct contact with eyes, ears, or open wounds, when contaminated food or water is ingested, or when bathing or swimming through incidental ingestion [47]. Waterborne pathogens may be zoonotic in origin, concentrated by bivalve shellfish such as mussels or oysters, or through crop irrigation [47]. Enteric organisms that are transmitted by the fecal oral route and naturally occurring bacteria and protozoa in aquatic systems are also pathogens of concern. Changes in climate, including temperature and precipitation patterns, can directly influence the growth, survival, persistence, transmission, and virulence of pathogens [47]. Disruptions to ecosystems and habitat for those species that are zoonotic reservoirs, also influence pathogen range, vigour, and expansion when hosts and vectors become dominant in depleted communities. Disrupted ecosystems affect zoonotic pathogens where species vary in their susceptibility to infection by a pathogen. Greater biodiversity often results in lower disease risk [47,48].

Rising temperatures are directly linked to an increased risk of enteric disease when groundwater, surface water or other drinking water sources are contaminated by flooding, runoff, or damaged infrastructure $[48,49]$. Changes in temperature and precipitation can influence enteric infections. Warmer and wetter conditions are favourable to the growth of bacterial pathogens on produce crops such as lettuce [50,51]. In addition, both drought and flooding conditions support pathogen adhesion to leafy crops [51,52]. Heavy rainfall events result in higher concentrations of enteric viruses in both drinking and recreational water $[51,53]$.

The strategy and associated outcomes described in Table 4 can help to reduce and prevent the spread of pathogens and vector-borne diseases, and food and waterborne illnesses through implementation of green infrastructure. Widespread implementation of different applications of green infrastructure across communities can regulate rising temperatures through evapotranspiration and shade provision. It can also reduce the burden of heavy rainfall events on stormwater infrastructure, and reduce runoff, nutrient loading, and contamination of tributaries and water bodies. Green infrastructure applications such as green roofing, urban vegetation, and forestry can effectively manage flood risk by facilitating water absorption and retention, in addition to reducing surface water run-off during rainfall events and related pollution [12,33,34]. In addition, green roofing and urban vegetation provide stormwater management capacity by slowing overland flows, reducing runoff, and increasing permeable surface area. Urbanization and sprawl have led to landscape fragmentation and reduced connectivity between green and blue spaces such as forests, rivers, stream, and lakes. This in turn has reduced natural habitat 
and diminished natural ecosystem functions and biodiversity. Widespread implementation of different green infrastructure applications can create a network of sites and spaces to provide species habitat and increase habitat connectivity and biodiversity $[14,33,34,44]$. The application of green infrastructure has been shown to enhance insect and vertebrate diversity and support ecosystem services such as pollination through the provision of habitat $[14,44]$.

Table 4. Strategy and associated outcomes from activities that increase the adaptive capacity of communities to reduce and prevent the spread of pathogens and vector-borne diseases; and food and waterborne illnesses through the application of green infrastructure.

\begin{tabular}{|c|c|}
\hline Strategy & Outcomes \\
\hline \multirow{5}{*}{$\begin{array}{l}\text { 3. Increase the adaptive capacity of communities to reduce and } \\
\text { prevent the spread of pathogens and vector-borne diseases, and } \\
\text { food and waterborne illnesses }\end{array}$} & - Reduce conditions favourable to pathogen spread \\
\hline & - Facilitate positive species response to climate change \\
\hline & $\begin{array}{l}\text { - Increase biodiversity to support zooprophylaxis and dilution } \\
\text { effect }\end{array}$ \\
\hline & - Improve water quality \\
\hline & - Reduce food miles and contamination pathways \\
\hline
\end{tabular}

\subsection{Climate Change Impact Category: Death}

Ontario's ecosystems are under extreme stress and face multiple threats from land use change and development resulting in fragmentation and habitat loss, in addition to toxic pollution [54]. The unsustainable harvesting of species and the spread of invasive species also threaten the biodiversity of the province [54]. As mentioned previously, climate change is a threat multiplier. For Ontario's ecosystems, it can exacerbate threats and stressors for example, by expanding the range and vigour of invasive species as temperatures grow warmer. Climate change presents a threat all its own to ecosystems and species through warmer air and water temperatures, decreasing ice cover and changing patterns of precipitation [54]. These changes will render some species of plants and animals native to Ontario, unable to survive while others will adapt to the changing climate. Range expansion of other plant, animal and insect species from outside Ontario is occurring. A case in point is the black legged tick which can transmit Lyme disease between animals and humans [55-57]. The occurrence and abundance of both native and invasive species is being affected by warming temperatures [54,57].

Aquatic ecosystems across the province are being affected by the changing climate in the distribution of fish species, their growth, and their reproduction and survival rates [54,57-59]. Warmer water temperatures are affecting stream flow and will lead to a decline in some cold-water fish species like lake and brook trout while warm-water species such as smallmouth bass and walleye will benefit with an anticipated northward habitat expansion [54]. Water quality is being affected by more frequent precipitation events resulting in increased nutrient levels in lakes [54,57]. Changes in sea ice cover are affecting Ontario's polar bears and reducing their survival rates through diminished hunting access and denning habitat $[60,61]$.

Changes in phenology including spring breeding cycles and the earlier onset of plant flowering are occurring. Changes in species distribution have occurred with an observed shift in northward range expansion and in migration patterns [57]. As a result, the composition and distribution of species are being negatively affected due to competition for resources, changes in interactions between species that interact or depend on one another for survival, such as predator-prey and host-parasite relationships, in addition to pollinator insects and flowering plants [54,57]. Warming temperatures are impacting northern Ontario from melting permafrost, to altered species distribution in the boreal forest, and the loss of peatlands, a major carbon sink in Ontario [54,62,63]. 
Climate change is not solely an environmental phenomenon. Humans are directly exposed to climate change and are at risk of adverse health outcomes from the impacts of climate change such as air pollution, extreme temperatures, and flooding. Climate related health risks include heat stress, reduced air and water quality, vector-borne diseases, water and foodborne illness, and food insecurity. Within urbanized areas, ozone $\left(\mathrm{O}_{3}\right)$, nitrogen dioxide $\left(\mathrm{NO}_{2}\right)$ and particulate matter $(\mathrm{PM})$ are the most abundant air pollutants [64] Ground level ozone has harmful environmental effects that include damage to vegetation and material damage to substances such as rubber $[2,5,65]$. Ground level ozone is very reactive and exposure can cause respiratory conditions including pulmonary inflammation and reduced lung capacity $[5,65,66]$. In addition to irritation of the eyes, nose, and lungs; ozone exposure can exacerbate pre-existing health conditions such as asthma and bronchitis [66-68]. Adverse human health effects from exposure to nitrogen dioxide include decreased lung function and exacerbation of respiratory conditions such as asthma, in addition to harmful environmental effects that include acid rain and eutrophication in water bodies $[2,69,70]$.

As the climate changes, extreme weather and temperature events will increase in intensity, frequency, and duration, resulting in amplified health risks for many people [47,68,71]. Extreme heat intensifies pollen and aeroallergen levels that trigger asthma [72]. Hotter temperatures will also increase heat stress and risks from food and waterborne illnesses $[47,71,72]$. In addition, people who are older, chronically ill, and socially disadvantaged are more vulnerable to the health effects of extreme heat that can include serious illness and even death $[47,71,72]$. Rising temperatures as a result of climate change will continue to intensify these problems $[47,71,73]$. Global climate change projections have indicated that temperatures will continue to rise and the frequency and intensity of heat waves will increase [47,71,74] although extreme cold events will likely decrease [75]. At a regional level, heat waves are projected to increase across Ontario due to rising temperatures $[27,76,77]$. People suffer illnesses and experience reduced quality of life when high temperatures occur for an extended period of time. Those who are older, chronically ill, and socially disadvantaged are more vulnerable to the health effects of extreme heat that can include serious illness and even death. Urbanization, social disparity, and an aging population will exacerbate the impact of rising temperatures.

The strategy and associated outcomes described in Table 5 can help to reduce and prevent species endangerment, extirpation, and extinction through the implementation of green infrastructure. Widespread implementation of different applications of green infrastructure across communities can reduce landscape fragmentation and increase connectivity between green and blue spaces such as forests, rivers, streams, and lakes. Implementation of green infrastructure can also rebuild natural habitat and restore natural ecosystem functions and biodiversity. Widespread implementation of different green infrastructure applications can create a network of sites and spaces to provide species habitat and increase habitat connectivity and biodiversity [14,78-81]. Green infrastructure also improves water quality by reducing flood risk, runoff, and pollution. It provides water storage during rainfall events, reducing overland flows, and preventing sediment erosion and nutrient loading $[14,33,35,36]$.

Table 5. Strategy and associated outcomes from activities that increase the adaptive capacity of communities to reduce and prevent species endangerment and extinction through the application of green infrastructure.

- Improve ecological connectivity

- Protect and restore aquatic and terrestrial ecosystems

- Enhance resilience of ecosystems and species

- Facilitate persistence of species-at-risk

- Enhance capacity of natural heritage areas to respond to the effects of climate change

4. Increase the adaptive capacity of communities to reduce and prevent species endangerment, extirpation, and extinction.
- Increase ecological health and propagation of long-lived tree and vegetative species

- Reduce fragmentation of natural areas, degraded water quality, and negative impacts to fish and wildlife habitat 
The application of green infrastructure regulates temperature and provides cooling capacity through evapotranspiration and surface shading. Green infrastructure has a moderating effect on temperature, providing cooling capacity, and reducing the urban heat island effect [10,82-87]. Green infrastructure applications have also been shown to improve health outcomes from extreme heat and air pollution $[3,9,13,88-93]$.

Air quality is improved by the application of green infrastructure through atmospheric deposition and immobilization of local air pollutants and particulate matter. Green infrastructure applications such as green roofs and green walls have been shown to reduce air pollutant concentrations and provide urban cooling $[3,9,85,94,95]$. Studies have shown that the application of green infrastructure can remove air pollutants including ozone, nitrogen dioxide, and particulate matter $[3,9,13,83,87,89,91]$. Other applications of green infrastructure such as urban vegetation strategies like tree and shrub plantings in urban corridors have also been shown to be effective in the immobilization of particulates, improvement of air quality, and reduction of temperatures $[3,9,13,86,96]$.

\section{Discussion}

The Climate Change Local Adaptation Action Model (CCLAAM) provides a decision support framework for deep resilience by facilitating the implementation of green infrastructure. It establishes a theory of change to address the impacts of climate change using Ontario, Canada as a case study. This decision-support framework accounts for the capacity of communities to implement different applications of green infrastructure by providing outcomes over the short, intermediate, and long term to address the four categories of climate change impacts. The framework provides a comprehensive and common understanding of the multiple applications of green infrastructure and the associated benefits. In addition, it can be applied across different spatial and temporal scales. It provides guidance to communities and decision-makers to evaluate which applications of green infrastructure are most appropriate to address the specific impacts of climate change within individual communities through land-use planning. This guidance can facilitate strategic application of green infrastructure as a complex climate change intervention in a coordinated way that maximizes environmental and human health co-benefits. This framework also directly contributes to the localized implementation of four UN SDGs and their associated targets as shown in Table 6.

Each deep resilience strategy corresponds with one or more of the UN SDGs and their associated targets. For example, strategy one supports two SDGs (i.e., Sustainable Cities \& Communities and Climate Action) and specific associated targets. On the other hand, strategy two supports four SDGs (i.e., Zero Hunger, Sustainable Cities \& Communities, Climate Action, and Life on Land). Strategies three and four each support three SDGs (i.e., Sustainable Cities \& Communities, Climate Action, and Life on Land). Table 6 provides a provides a cross-stream translation with each strategy supporting the SDG for Climate Action. There are linkages and interdependencies between the SDGs. Addressing climate change can have positive benefits for biodiversity while sustainable agricultural practices can achieve food security, in addition to reducing both poverty and greenhouse gas emissions.

Currently, there are no green infrastructure implementation support tools comparable to the CCLAAM. Other green infrastructure implementation support tools include an ecosystem services analysis process for regenerative urban design [97], a conceptual framework to support nature-based solutions in urban areas [98], a set of urban design principles for the application of vegetation in urban areas [99], a hierarchical framework to prioritize the implementation of urban green space [100], and a geo-information system (GIS) based adaptation support tool for planning urban blue and green spaces [12]. The CCLAAM is uniquely different from these other tools because it is built around a central theory of change that is applicable to all communities and is not exclusive to urban settings. In addition, the CCLAAM provides a series of activities and associated outcomes to enable 
evaluation and strategic selection of multiple green infrastructure applications to address the impacts of climate change on individual communities.

Table 6. Deep Resilience strategies and corresponding UN SDGs and targets.

\begin{tabular}{|c|c|c|}
\hline Deep Resilience Strategies & UN SDGs & SDG Targets \\
\hline \multirow[t]{2}{*}{$\begin{array}{l}\text { 1: Increase the adaptive capacity of } \\
\text { communities to reduce resource conflict } \\
\text { and security threats }\end{array}$} & $\begin{array}{l}\text { Goal 11-Sustainable Cities and } \\
\text { Communities: Make cities and human } \\
\text { settlements inclusive, safe, resilient, and } \\
\text { sustainable }\end{array}$ & $\begin{array}{l}\text { 11.5 By 2030, significantly reduce the } \\
\text { number of deaths and the number of } \\
\text { people affected and substantially } \\
\text { decrease the direct economic losses } \\
\text { relative to global gross domestic product } \\
\text { caused by disasters, including } \\
\text { water-related disasters, with a focus on } \\
\text { protecting the poor and people in } \\
\text { vulnerable situations } \\
\text { 11.6 By 2030, reduce the adverse per } \\
\text { capita environmental impact of cities, } \\
\text { including by paying special attention to } \\
\text { air quality and municipal and other } \\
\text { waste management } \\
\text { 11.7 By 2030, provide universal access to } \\
\text { safe, inclusive and accessible, green and } \\
\text { public spaces, in particular for women } \\
\text { and children, older persons and persons } \\
\text { with disabilities } \\
\text { 11.a Support positive economic, social } \\
\text { and environmental links between urban, } \\
\text { peri-urban and rural areas by } \\
\text { strengthening national and regional } \\
\text { development planning } \\
\text { 11.b By 2020, substantially increase the } \\
\text { number of cities and human settlements } \\
\text { adopting and implementing integrated } \\
\text { policies and plans towards inclusion, } \\
\text { resource efficiency, mitigation and } \\
\text { adaptation to climate change, resilience } \\
\text { to disasters, and develop and implement, } \\
\text { in line with the Sendai Framework for } \\
\text { Disaster Risk Reduction } 2015-2030, \\
\text { holistic disaster risk management at all } \\
\text { levels }\end{array}$ \\
\hline & $\begin{array}{l}\text { Goal 13-Climate Action: Take urgent } \\
\text { action to combat climate change and its } \\
\text { impacts }\end{array}$ & $\begin{array}{l}\text { 13.1 Strengthen resilience and adaptive } \\
\text { capacity to climate-related hazards and } \\
\text { natural disasters in all countries }\end{array}$ \\
\hline
\end{tabular}

2.4 By 2030, ensure sustainable food production systems and implement resilient agricultural practices that increase productivity and production, that help maintain ecosystems, that strengthen capacity for adaptation to climate change, extreme weather, drought, flooding and other disasters and that progressively improve land and soil quality

Goal 11-Sustainable Cities and

Communities
11.5, 11.6, 11.7, 11.a, 11.b 
Table 6. Cont

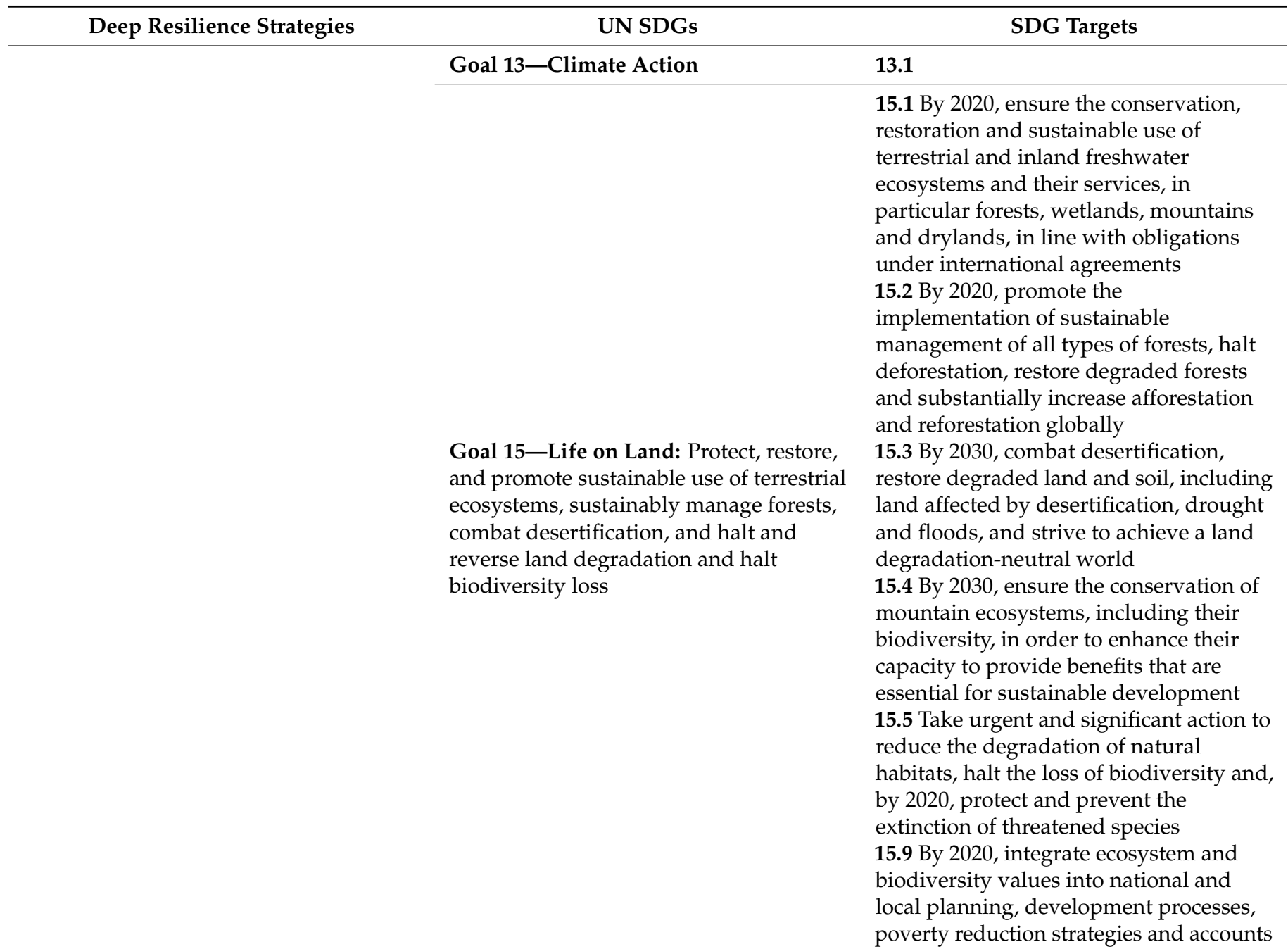

\begin{tabular}{|c|c|c|}
\hline \multirow{3}{*}{$\begin{array}{l}\text { 3: Increase the adaptive capacity of } \\
\text { communities to reduce and prevent the } \\
\text { spread of pathogens and vector-borne } \\
\text { diseases, and food and waterborne } \\
\text { illnesses }\end{array}$} & $\begin{array}{l}\text { Goal 11-Sustainable Cities and } \\
\text { Communities }\end{array}$ & 11.5, 11.6, 11.7, 11.a, 11.b \\
\hline & Goal 13-Climate Action & 13.1 \\
\hline & Goal 15-Life on Land & $15.1,15.2,15.3,15.4,15.5,15.9$ \\
\hline \multirow{3}{*}{$\begin{array}{l}\text { 4: Increase the adaptive capacity of } \\
\text { communities to reduce and prevent } \\
\text { species endangerment, extirpation, and } \\
\text { extinction. }\end{array}$} & $\begin{array}{l}\text { Goal 11-Sustainable Cities and } \\
\text { Communities }\end{array}$ & 11.5, 11.6, 11.7, 11.a, 11.b \\
\hline & Goal 13-Climate Action & 13.1 \\
\hline & Goal 15-Life on Land & $15.1,15.2,15.3,15.4,15.5,15.9$ \\
\hline
\end{tabular}

The ecosystem system service analysis process for regenerative design put forward by Zari (2015) [97] is focused on incorporating green infrastructure (e.g., forestry and vegetation) in highly urbanized settings to restore ecosystem function and service provision to pre-development levels in New Zealand. This tool does not provide activities or outcomes to support the implementation of green infrastructure rather it provides another lens in setting environmental performance goals within urban development. The conceptual framework to support nature-based solutions in urban areas put forward by Connop et al. (2016) [98] identifies the benefits and ecosystem services associated with green infrastructure (e.g., trees and vegetation) and potential barriers to implementation to support effective green infrastructure development in urban centres in England and Germany. The urban design principles for the application of vegetation in urban areas put forward by Kleerekoper et al. (2012) [99] are focused on incorporating vegetation, water, compact built 
form, and reflective or permeable materials into urban development specifically to reduce urban heat island effect in the Netherlands. The hierarchical framework to prioritize the implementation of urban green space put forward by Norton et al. (2015) [100] provides a prioritization framework to reduce extreme heat events using green infrastructure (e.g., trees, vegetation, green roofs and walls) in urban areas in Australia. The geo-information system (GIS) based adaptation support tool put forward by Voskamp and Van de Ven (2015) [12] is focused on increasing the adaptive capacity of urban areas in the Netherlands specifically to flooding, drought and extreme heat using green and blue infrastructure (e.g., trees and vegetation, green roofs and walls, and various types of water infrastructure).

The CCLAAM is a novel decision-support framework that illustrates how multiple green infrastructure applications can specifically address the impacts of climate change when strategically applied within individual communities. The CCLAAM provides a multifaceted solution to the challenges presented by different urban, suburban, and peri-urban morphologies across Ontario, Canada. It would be beneficial to test the CCLAAM in communities that are representative of different urban, suburban, and peri-urban morphologies to further refine it. To understand how it performs within different contexts, it would also be beneficial to test the CCLAAM with the participation of different communities and decision-making organizations such as municipalities; Indigenous communities; public health agencies; real estate management companies; or academic institutions with real estate assets.

\section{Conclusions}

This decision-support framework can assist communities in harnessing the four horsemen of climate change using green infrastructure as a complex nature-based intervention. Without a common lexicon and shared understanding, the pace of uptake and mainstream implementation of green infrastructure will be slow. Enabling climate resilient pathways that enable both mitigation and adaptation for sustainable development are essential for reducing negative anthropogenic influence on the climate system. The CCLAAM is a novel decision-support framework that illustrates how multiple green infrastructure applications can specifically address the impacts of climate change when strategically applied within individual communities. This framework enables deep resilience through the coordinated and strategic implementation of multiple applications of green infrastructure while localizing implementation of the UN SDGs at the community level. It also maximizes environmental and human health co-benefits and accounts for local variation in knowledge, capacity, and resources by providing multiple green infrastructure applications suitable for different urban, suburban, and peri-urban morphologies.

Author Contributions: V.A. and W.A.G. contributed to the study conception and design. Material preparation, data collection and analysis were performed by V.A. The first draft of the manuscript was written by V.A. and W.A.G. contributed to the editing process. Both have read and approved the final manuscript. All authors have read and agreed to the published version of the manuscript.

Funding: The authors are supported by W.A.G.'s Natural Sciences and Engineering Research Council of Canada (NSERC) Grant RGPIN-2018-06801.

Institutional Review Board Statement: Not applicable.

Informed Consent Statement: Not applicable.

Data Availability Statement: The data presented in this study are available on request from the corresponding author.

Conflicts of Interest: The authors declare that there are no conflicts of interest. 


\section{References}

1. Solomon, S.; Qin, D.; Manning, M.; Chen, Z.; Marquis, M.; Averyt, K.B.; Tignor, M.; Miller, H.L. Climate Change 2007: The Physical Science Basis. Contribution of Working Group I to the Fourth Assessment Report of the Intergovernmental Panel on Climate Change; Solomon, S., Qin, D., Manning, M., Chen, Z., Marquis, M., Averyt, K.B., Tignor, M., Miller, H.L., Eds.; Cambridge University Press: Cambridge, UK; New York, NY, USA, 2007.

2. Environment and Climate Change Canada. Canadian Environmental Sustainability Indicators: Air Quality. 2016. Available online: www.ec.gc.ca/indicateurs-indicators / default.asp?lang=en\&n=7DCC2250-1 (accessed on 5 July 2018).

3. Anderson, V.; Gough, W.A. Evaluating the potential of nature-based solutions to reduce ozone, nitrogen dioxide, and carbon dioxide through a multi-type green infrastructure study in Ontario, Canada. City Environ. Interact. 2020, 6, 100043. [CrossRef]

4. Environmental Protection Agency (EPA). Health Effects of Ozone Pollution. 2019. Available online: https://www.epa.gov/ ground-level-ozone-pollution/health-effects-ozone-pollution (accessed on 1 June 2020).

5. Ministry of Environment, Conservation \& Parks. Ground Level Ozone. 2010. Available online: http:/ / www.airqualityontario. com/science/pollutants/ozone.php (accessed on 1 June 2020).

6. United Nations. The 2030 Agenda for Sustainable Development. 2015. Available online: https:/ /sustainabledevelopment.un org/content/documents/21252030\%20Agenda\%20for\%20Sustainable\%20Development\%20web.pdf (accessed on 1 June 2020).

7. Government of Canada. Towards Canada's 2030 Agenda National Strategy. 2019. Available online: https://www.canada.ca/ content/dam/esdc-edsc/documents/programs/agenda-2030/7781_EmploymentSocialDevelopment_2030-ENv5.pdf (accessed on 1 June 2020).

8. Anderson, V. Deep Adaptation: A Framework for Climate Resilience, Decarbonization and Planetary Health in Ontario. Ph.D. Dissertation, University of Toronto, Toronto, ON, Canada, 2018. Available online: https://tspace.library.utoronto.ca/ (accessed on 1 June 2020).

9. Anderson, V.; Gough, W.A. Form, Function, and Nomenclature: Deconstructing Green Infrastructure and its Role in a Changing Climate. In Climate Change and Extreme Events; Fares, A., Ed.; Elsevier: Amsterdam, The Netherlands, 2021; ISBN U1104201903351.

10. Berardi, U.; AmirHosein, G.H.; Ali, G. State-of-the-art analysis of the environmental benefits of green roofs. Appl. Energy 2014, 115, 411-428. [CrossRef]

11. Marchi, M.; Pulselli, R.M.; Marchettini, N.; Pulselli, F.M.; Bastianoni, S. Carbon dioxide sequestration model of a vertical greenery system. Ecol. Model. 2015, 306, 46-56. [CrossRef]

12. Voskamp, I.M.; Van de Ven, F.H.M. Planning support system for climate change: Composing effective sets of blue-green measures to reduce urban vulnerability to extreme weather events. Build. Environ. 2014, 283, 159-167.

13. Nowak, D.J.; Crane, D.E.; Stevens, J.C. Air pollution removal by urban trees and shrubs in the United States. Urban Urban Green 2006, 4, 115-123. [CrossRef]

14. Lin, B.B.; Philpott, S.M.; Jha, S. The future of urban agriculture and biodiversity-ecosystem services: Challenges and next steps. Basic Appl. Ecol. 2015, 16, 189-201. [CrossRef]

15. Thornbush, M.J. Vehicular Air Pollution and Urban Sustainability: An Assessment from Central Oxford, UK; Springer Briefs in Geography; Springer: Berlin/Heidelberg, Germany, 2015.

16. Thevathasan, N.V.; Gordon, A.M. Ecology of tree intercropping systems in the North temperate region: Experiences from southern Ontario, Canada. Agrofor. Syst. 2004, 61, 257-268.

17. Denton, F.; Wilbanks, T.J.; Abeysinghe, A.C.; Burton, I.; Gao, Q.; Lemos, M.C.; Masui, T.; O’Brien, K.L.; Warner, K. Climate-resilient pathways: Adaptation, mitigation, and sustainable development. In Climate Change 2014: Impacts, Adaptation, and Vulnerability. Part A: Global and Sectoral Aspects. Contribution of Working Group II to the Fifth Assessment Report of the Intergovernmental Panel on Climate Change; Field, C.B., Barros, V.R., Dokken, D.J., Mach, K.J., Mastrandrea, M.D., Bilir, T.E., Chatterjee, M., Ebi, K.L., Estrada, Y.O., Genova, R.C., et al., Eds.; Cambridge University Press: Cambridge/London, UK, 2014; pp. 1101-1131.

18. Taplin, D.H.; Clark, H.; Collins, E.; Colby, D.C. Theory of Change Technical Papers A Series of Papers to Support Development of Theories of Change Based on Practice in the Field; ActKnowledge: New York, NY, USA, 2013; Available online: http:/ / www.actknowledge. org/resources/documents/ToC-Tech-Papers.pdf (accessed on 1 June 2020).

19. Centre for Theory of Change. Theory of Change Origins. 2013. Available online: http://www.theoryofchange.org/what-istheory-of-change/toc-background/toc-origins / (accessed on 1 June 2020).

20. Weiss, C.H. How Can Theory-Based Evaluation Make Greater Headway? Eval. Rev. 1997, 21, 501-524. [CrossRef]

21. Weiss, C.H. Nothing as Practical as Good Theory: Exploring Theory-based Evaluation for Comprehensive Community Initiatives for Children and Families. In New Approaches to Evaluating Community Initiatives: Concepts, Methods, and Contexts; Connell, J.P., Kubisch, A.C., Schorr, L.B., Weiss, C.H., Eds.; Aspen Institute: Washington, DC, USA, 1995.

22. World Health Organization (WHO). Health Impact Assessment. 2017. Available online: https://www.who.int/heli/impacts/ hiabrief/en/ (accessed on 1 June 2020).

23. National Collaborating Centre for Healthy Public Policy. Health Impact Assessment. 2010. Available online: http:/ / www.ncchpp. ca/54/Health_Impact_Assessment.ccnpps (accessed on 1 June 2020).

24. Organization for Economic Co-Operation and Development. Framework for Regulatory Policy Evaluation. 2014. Available online: http:/ / www.keepeek.com/Digital-Asset-Management/oecd/governance/oecd-framework-for-regulatory-policyevaluation_9789264214453-en\#page7 (accessed on 1 June 2020). 
25. Organization for Economic Co-operation and Development. Building and Institutional Framework for Regulatory Impact Analysis: Guidance for Policy Makers. 2008. Available online: https://www.oecd.org/gov/regulatory-policy/40984990.pdf (accessed on 1 June 2020).

26. Adger, W.N.; Pulhin, J.; Barnett, G.D.; Dabelko, G.K.; Hovelsrud, M.; Levy, Ú.; Oswald, S.; Vogel, C.H. 2014: Human security. In Climate Change 2014-Impacts, Adaptation, and Vulnerability. Part A: Global and Sectoral Aspects. Contribution of Working Group II to the Fifth Assessment Report of the Intergovernmental Panel on Climate Change; Field, C.B., Barros, V.R., Dokken, D.J., Mach, K.J., Mastrandrea, M.D., Bilir, T.E., Chatterjee, M., Ebi, K.L., Estrada, Y.O., Genova, R.C., et al., Eds.; Cambridge University Press: London, UK, 2014; pp. 755-791.

27. Gough, W.; Anderson, V.; Herod, K. Ontario Climate Change and Health Modelling Study: Report; Ontario Ministry of Health and Long-Term Care, Queen's Printer for Ontario: Ontario, ON, Canada, 2016. [CrossRef]

28. Barnett, J.; Adger, W.N. Climate change, human security and violent conflict. Politi. Geogr. 2007, 26, 639-655. [CrossRef]

29. Center for Climate \& Security. Climate Security 101. 2015. Available online: https:/ / climatesecurity101.files.wordpress.com/20 15/02/climate-security-101-2_21_15.pdf (accessed on 1 June 2020).

30. Department of Defense. Climate-Related Risk to DoD Infrastructure Initial Vulnerability Assessment Survey (SLVAS) Report. 2018. Available online: https:/ / climateandsecurity.files.wordpress.com/2018/01/tab-b-slvas-report-1-24-2018.pdf (accessed on 1 June 2020).

31. Rüttinger, L.; Stang, G.; Smith, D.; Tänzler, D.; Vivekananda, J.; Brown, O.; Carius, A.; Dabelko, G.; De Souza, R.M.; Mitra, S.; et al. A New Climate for Peace_-Taking Action on Climate and Fragility Risks; The Wilson Center, Adelphi, International Alert, European Union Institute for Security Studies: Berlin, Germany, 2015.

32. Werrell, C.E.; Femia, F.; Goodman, S.; Fetzek, S. A Responsibility to Prepare: Governing in an Age of Unprecedented Risk and Unprecedented Foresight. The Centre for Climate \& Security. 2017. Available online: https:// climateandsecurity.files.wordpress com/2017/12/a-responsibility-to-prepare_governing-in-an-age-of-unprecedented-risk-and-unprecedented-foresight_briefer38.pdf (accessed on 1 June 2020).

33. Ellis, J. Sustainable surface water management and green infrastructure in UK urban catchment planning. J. Environ. Plan. Manag. 2013, 56, 24-41. [CrossRef]

34. Lennon, M.; Scott, M.; O’Neill, E. Urban Design and Adapting to Flood Risk: The Role of Green Infrastructure. J. Urban Des. 2014, 19, 745-758. [CrossRef]

35. Rowe, D.B. Green roofs as a means of pollution abatement. Environ. Pollut. 2011, 159, 2100-2110. [CrossRef]

36. Plascencia-Escalante, F. An Analysis of Some Components of the Nitrogen Cycle as Affected by Land Use Adjacent to the Riparian zone of a Southern Ontario Stream. Ph.D. Thesis, University of Guelph, Guelph, ON, Canada, 2008.

37. FAO. Strengthening coherence in FAO's initiatives to fight hunger (Item 10). In Proceedings of the Conference Thirty-Second Session, Rome, Italy, 29 November-10 December 2003.

38. IPCC. Climate Change 2007: Impacts, Adaptation and Vulnerability. Contribution of Working Group II to the Fourth Assessment Report of the Intergovernmental Panel on Climate Change; Parry, M.L., Canziani, O.F., Palutikof, J.P., van der Linden, P.J., Hanson, C.E., Eds.; Cambridge University Press: Cambridge, UK, 2007; p. 976.

39. Fischer, G.; Shah, M.; Tubiello, F.N.; Van Velhuizen, H. Socio-economic and climate change impacts on agriculture: An integrated assessment, 1990-2080. Philos. Trans. R. Soc. B Biol. Sci. 2005, 360, 2067-2083. [CrossRef]

40. Hitz, S.; Smith, J. Estimating global impacts from climate change. Glob. Environ. Chang. 2004, 14, 201-218. [CrossRef]

41. Parry, M.; Rosenzweig, C.; Livermore, M. Climate change, global food supply and risk of hunger. Philos. Trans. R. Soc. B Biol. Sci. 2005, 360, 2125-2138. [CrossRef]

42. FAO. Future Climate Change and Regional Fisheries: A Collaborative Analysis; FAO Fisheries Technical Paper No. 452; Food and Agriculture Organization of the United Nations: Rome, Italy, 2003; p. 75.

43. Thornbush, M.J. Urban agriculture in the transition to low carbon cities through urban greening. Aims Environ. Sci. 2015, 2, 852-867. [CrossRef]

44. Williams, N.S.G.; Lundholm, J.T.; MacIvor, J.S. FORUM: Do green roofs help urban biodiversity conservation? J. Appl. Ecol. 2014, 51, 1643-1649. [CrossRef]

45. Thevathasan, N.V.; Gordon, A.; Bradley, R.; Cogliastro, A.; Folkard, P.; Grant, R.F.; Kort, J.; Liggins, L.; Njenga, F.; Olivier, A.; et al. Agroforestry Research and Development in Canada: The Way Forward. In Agroforestry-The Future of Global Land Use; Springer: Berlin/Heidelberg, Germany, 2012; Volume 9, pp. 247-283. [CrossRef]

46. Wotherspoon, A.; Thevathasan, N.V.; Gordon, A.M.; Voroney, R.P. Carbon sequestration potential of five tree species in a 25-year-old temperate tree-based intercropping system in southern Ontario, Canada. Agrofor. Syst. 2014, 88, 631-643. [CrossRef]

47. Smith, K.R.; Woodward, A.; Campbell-Lendrum, D.; Chadee, D.D.; Honda, Y.; Liu, Q.; Olwoch, J.M.; Revich, B.; Sauerborn, R. Human Health: Impacts, Adaptation, and Co-Benefits. In Climate Change 2014: Impacts, Adaptation, and Vulnerability. Part A: Global and Sectoral Aspects. Contribution of Working Group II to the Fifth Assessment Report of the Intergovernmental Panel on Climate Change; Field, C.B., Barros, V.R., Dokken, D.J., Mach, K.J., Mastrandrea, M.D., Bilir, T.E., Chatterjee, M., Ebi, K.L., Estrada, Y.O., Genova, R.C., et al., Eds.; Cambridge University Press: Cambridge, MA, USA; London, UK, 2014; pp. 709-754.

48. Khalil, H.; Ecke, F.; Evander, M.; Magnusson, M.; Hörnfeldt, B. Declining ecosystem health and the dilution effect. Sci. Rep. 2016, 6, 31314. [CrossRef] [PubMed] 
49. Martin, D.; Bélanger, D.; Gosselin, P.; Brazeau, J.; Furgal, C.; Déry, S. Drinking Water and Potential Threats to Human Health in Nunavik: Adaptation Strategies under Climate Change Conditions. Arctic 2009, 60, 195-202. [CrossRef]

50. Liu, C.; Hofstra, N.; Franz, E. Impacts of climate change on the microbial safety of pre-harvest leafy green vegetables as indicated by Escherichia coli O157 and Salmonella spp. Int. J. Food Microbiol. 2013, 163, 119-128. [CrossRef] [PubMed]

51. Smith, P.; Bustamante, M.; Ahammad, H.; Clark, H.; Dong, H.; Elsiddig, E.A.; Haberl, H.; Harper, R.; House, J.; Jafari, M.; et al. Agriculture, Forestry and Other Land Use (AFOLU). In Climate Change 2014: Mitigation of Climate Change. Contribution of Working Group III to the Fifth Assessment Report of the Intergovernmental Panel on Climate Change; Edenhofer, O., Pichs-Madruga, R., Sokona, Y., Farahani, E., Kadner, S., Seyboth, K., Adler, A., Baum, I., Brunner, S., Eickemeier, P., et al., Eds.; Cambridge University Press: Cambridge, MA, USA; London, UK, 2014.

52. Ge, C.; Lee, C.; Lee, J. The impact of extreme weather events on Salmonella internalization in lettuce and green onion. Food Res. Int. 2012, 45, 1118-1122. [CrossRef]

53. Delpla, I.; Jung, A.-V.; Baures, E.; Clement, M.; Thomas, O. Impacts of climate change on surface water quality in relation to drinking water production. Environ. Int. 2009, 35, 1225-1233. [CrossRef]

54. Environmental Commissioner of Ontario. Feeling the Heat: Greenhouse Gas Progress Report 2015; Queen's Printer for Ontario: Ontario, ON, Canada, 2015.

55. Ogden, N.H.; Radojevic, M.; Wu, X.; Duvvuri, V.R.; Leighton, P.A.; Wu, J. Estimated Effects of Projected Climate Change on the Basic Reproductive Number of the Lyme Disease VectorIxodes scapularis. Environ. Health Perspect. 2014, 122, 631-638. [CrossRef]

56. Ogden, N.H.; St-Onge, L.; Barker, I.K.; Brazeau, S.; Bigras-Poulin, M.; Charron, D.F.; Francis, C.M.; Heagy, A.; Lindsay, L.R.; Maarouf, A.; et al. Risk maps for range expansion of the Lyme disease vector, Ixodes scapularis, in Canada now and with climate change. Int. J. Health Geogr. 2008, 7, 24. [CrossRef] [PubMed]

57. Warren, F.J.; Lemmen, D.S. Canada in a Changing Climate: Sector Perspectives on Impacts and Adaptation; Government of Canada: Ottawa, ON, Canada, 2014; p. 286.

58. Hori, Y.; Tam, B.; Gough, W.A.; Ho-Foong, E.; Karagatzides, J.D.; Liberda, E.N.; Tsuji, L.J.S. Use of Traditional Environmental Knowledge to Assess the Impact of Climate Change on Subsistence Fishing in the James Bay Region of Northern Ontario, Canada. Rural. Remote. Health 2012, 12, 1878.

59. Tam, B.Y.; Gough, W.A.; Tsuji, L. The impact of warming on the appearance of furunculosis in fish of the James Bay region, Quebec, Canada. Reg. Environ. Chang. 2011, 11, 123-132. [CrossRef]

60. Desrocher, A.E.; Aars, J.; Amstrup, S.C.; Cutting, A.; Lunn, N.J.; Molnár, P.K.; Obbard, M.E.; Stirling, I.; Thiemann, G.W.; Vongraven, D.; et al. Rapid Ecosystem Change and Polar Bear Conservation. Conserv. Lett. 2013, 6, 368-375.

61. Kowal, S.; Gough, W.A.; Butler, K. Temporal evolution of Hudson Bay Sea Ice (1971-2011). Appl. Clim. 2015, 127, 753-760. [CrossRef]

62. Gough, W.A.; Leung, A. Nature and fate of Hudson Bay permafrost. Reg. Environ. Chang. 2002, 2, 177-184. [CrossRef]

63. Tam, A.; Gough, W.A.; Kowal, S.; Xie, C. The Fate of Hudson Bay Lowlands Palsas in a Changing Climate. Arct. Antarct. Alp. Res. 2014, 46, 114-120. [CrossRef]

64. Hassan, N.A.; Hashim, Z.; Hashim, J.H. Impact of Climate Change on Air Quality and Public Health in Urban Areas. Asia Pac. J. Public Health 2015, 28, 38-48. [CrossRef] [PubMed]

65. Environmental Protection Agency (EPA). Ecosystem Effects of Ozone Pollution. 2017. Available online: https://www.epa.gov / ground-level-ozone-pollution/ecosystem-effects-ozone-pollution (accessed on 1 June 2020).

66. Stieb, D.M.; Szyszkowicz, M.; Rowe, B.H.; Leech, J. Air pollution and emergency department visits for cardiac and respiratory conditions: A multi-city time-series analysis. Environ. Health 2009, 8, 25. [CrossRef] [PubMed]

67. Berry, P.; Clarke, K.; Fleury, M.D.; Parker, S. Human Health. In Canada in a Changing Climate: Sector Perspectives on Impacts and, Adaptation; Warren, F.J., Lemmen, D.S., Eds.; Government of Canada: Ottawa, ON, Canada, 2014; pp. $191-232$.

68. Seguin, J. Human Health in a Changing Climate: A Canadian Assessment of Vulnerabilities and Adaptive Capacity; Government of Canada: Ottawa, ON, Canada, 2008; pp. 47-97.

69. Cibella, F.; Cuttitta, G.; Della Maggiore, R.; Ruggieri, S.; Panunzi, S.; De Gaetano, A.; Bucchieri, S.; Drago, G.; Melis, M.R.; La Grutta, S.; et al. Effect of Indoor Nitrogen Dioxide on Lung Function in Urban Environment. Environ. Res. 2015, 138, 8-16. [CrossRef] [PubMed]

70. IISD. Cost of Pollution in Canada: Measuring the Impacts on Families, Businesses and Governments; International Institute for Sustainable Development: Winnipeg, MB, Canada, 2017; ISBN 978-1-894784-76-4.

71. Watts, N.; Adger, W.N.; Agnolucci, P.; Blackstock, J.; Byass, P.; Cai, W.; Chaytor, S.; Colbourn, T.; Collins, M.; Cooper, A.; et al. Health and climate change: Policy responses to protect public health. Lancet 2015, 386, 1861-1914. [CrossRef]

72. Public Health Agency of Canada (PHAC). Climate Change and Public Health. Fact Sheet. 2015. Available online: http: / / www.phac-aspc.gc.ca/hp-ps / eph-esp/fs-fi-a-eng.php (accessed on 1 June 2020).

73. WHO. COP24 Special Report: Health and Climate Change. 2018. Available online: https://apps.who.int/iris/bitstream/handle/ 10665/276405/9789241514972-eng.pdf?ua=1 (accessed on 1 June 2020). 
74. Hartmann, D.L.; Klein Tank, A.M.G.; Rusticucci, M.; Alexander, L.V.; Brönnimann, S.; Charabi, Y.A.-R.; Dentener, F.J.; Dlugokencky, E.J.; Easterling, D.R.; Kaplan, A.; et al. Observations: Atmosphere and Surface. In Climate Change 2013: The Physical Science Basis. Contribution of Working Group I to the Fifth Assessment Report of the Intergovernmental Panel on Climate Change; Stocker, T.F., Qin, D., Plattner, G.K., Tignor, M., Allen, S.K., Boschung, J., Nauels, A., Xia, Y., Bex, V., Midgley, P.M., Eds.; Cambridge University Press: Cambridge, MA, USA; London, UK, 2013; pp. 159-254.

75. Gough, W.A.; Tam, B.Y.; Mohsin, T.; Allen, S.M. Extreme cold weather alerts in Toronto, Ontario, Canada and the impact of a changing climate. Urban Clim. 2014, 8, 21-29. [CrossRef]

76. Bustinza, R.; Lebel, G.; Gosselin, P.; Bélanger, D.; Chebana, F. Health impacts of the July 2010 heat wave in Québec, Canada. Bmc Public Health 2013, 13, 56. [CrossRef]

77. Price, K.; Perron, S.; King, N. Implementation of the Montreal Heat Response Plan During the 2010 Heat Wave. Can. J. Public Health 2013, 104, e96-e100. [CrossRef]

78. Francis, R.A. Wall ecology: A frontier for urban biodiversity and ecological engineering. Prog. Phys. Geogr. Earth Environ. 2010, 35, 43-63. [CrossRef]

79. Oberndorfer, E.; Lundholm, J.; Bass, B.; Coffman, R.R.; Doshi, H.; Dunnett, N.; Gaffin, S.; Köhler, M.; Liu, K.K.Y.; Rowe, B. Green Roofs as Urban Ecosystems: Ecological Structures, Functions, and Services. Bioscience 2007, 57, 823-833. [CrossRef]

80. Parkins, K.; Clark, J. Green roofs provide habitat for urban bats. Glob. Ecol. Conserv. 2015, 4, 349-357. [CrossRef]

81. Tonietto, R.; Fant, J.; Ascher, J.; Ellis, K.; Larkin, D. A comparison of bee communities of Chicago green roofs, parks and prairies. Landsc. Urban Plan. 2011, 103, 102-108. [CrossRef]

82. Alexandri, E.; Jones, P. Temperature decreases in an urban canyon due to green walls and green roofs in diverse climates. Build. Environ. 2008, 43, 480-493. [CrossRef]

83. Baik, J.; Kwak, K.-H.; Park, S.-B.; Ryu, Y.-H. Effects of building roof greening on air quality in street canyons. Atmos. Environ. 2012, 61, 48-55. [CrossRef]

84. Bowler, D.E.; Buyung-Ali, L.; Knight, T.M.; Pullin, A.S. Urban greening to cool towns and cities: A systematic review of the empirical evidence. Landsc. Urban Plan. 2010, 97, 147-155. [CrossRef]

85. Feng, H.; Hewage, K. Lifecycle assessment of living walls: Air purification and energy performance. J. Clean. Prod. 2014, 69, 91-99. [CrossRef]

86. Hall, J.M.; Handley, J.F.; Ennos, A.R. The potential of tree planting to climate-proof high density residential areas in Manchester, UK. Landsc. Urban Plan. 2012, 104, 410-417. [CrossRef]

87. Yang, J.; Yu, Q.; Gong, P. Quantifying air pollution removal by green roofs in Chicago. Atmos. Environ. 2008, 42, 7266-7273. [CrossRef]

88. Chen, D.; Wang, X.; Thatcher, M.; Barnett, G.B.; Kachenko, A.; Prince, R. Urban vegetation for reducing heat related mortality. Environ. Pollut. 2014, 192, 275-284. [CrossRef]

89. King, K.L.; Johnson, S.; Kheirbek, I.; Lu, J.W.; Matte, T. Differences in magnitude and spatial distribution of urban forest pollution deposition rates, air pollution emissions, and ambient neighborhood air quality in New York City. Landsc. Urban Plan. 2014, 128, 14-22. [CrossRef]

90. Tan, C.L.; Wong, N.H.; Jusuf, S.K. Effects of vertical greenery on mean radiant temperature in the tropical urban environment. Landsc. Urban Plan. 2014, 127, 52-64. [CrossRef]

91. Rao, M.; George, L.A.; Rosenstiel, T.N.; Shandas, V.; Dinno, A. Assessing the relationship among urban trees, nitrogen dioxide, and respiratory health. Environ. Pollut. 2014, 194, 96-104. [CrossRef] [PubMed]

92. Susca, T.; Gaffin, S.R.; Dell'Osso, G.R. Positive effects of vegetation: Urban heat island and green roofs. Environ. Pollut. 2011, 159, 2119-2126. [CrossRef] [PubMed]

93. Tzoulas, K.; Korpela, K.; Venn, S.; Yli-Pelkonen, V.; Kaźmierczak, A.; Niemelä, J.; James, P. Promoting ecosystem and human health in urban areas using Green Infrastructure: A literature review. Landsc. Urban Plan. 2007, 81, 167-178. [CrossRef]

94. Kessler, R. Urban Gardening: Managing the Risks of Contaminated Soil. Environ. Health Perspect. 2013, 121, A326-A333. [CrossRef]

95. Speak, A.; Rothwell, J.J.; Lindley, S.J.; Smith, C.L. Urban particulate pollution reduction by four species of green roof vegetation in a UK city. Atmos. Environ. 2012, 61, 283-293. [CrossRef]

96. Weber, F.; Kowarik, I.; Säumel, I. Herbaceous plants as filters: Immobilization of particulates along urban street corridors. Environ. Pollut. 2014, 186, 234-240. [CrossRef]

97. Zari, M.P. Ecosystem services analysis: Mimicking ecosystem services for regenerative urban design. Int. J. Sustain. Built Environ. 2015, 4, 145-157. [CrossRef]

98. Connop, S.; Vandergert, P.; Eisenberg, B.; Collier, M.J.; Nash, C.; Clough, J.; Newport, D. Renaturing cities using a regionallyfocused biodiversity-led multi-functional benefits approach to urban green infrastructure. Environ. Sci. Policy 2016, 62, 99-111. [CrossRef]

99. Kleerekoper, L.; Van Esch, M.; Salcedo, T.B. How to make a city climate-proof, addressing the urban heat island effect. Resour. Conserv. Recycl. 2012, 64, 30-38. [CrossRef]

100. Norton, B.; Coutts, A.; Livesley, S.J.; Harris, J.R.; Hunter, A.M.; Williams, N.S.G. Planning for cooler cities: A framework to prioritize green infrastructure to mitigate high temperatures in urban landscapes. Landsc. Urban Plan. 2015, 144, 127-138. [CrossRef] 